\title{
Detection of Elm Yellows Phytoplasma in EIms and Insects Using Real-Time PCR
}

Padmini Herath, Department of Plant Pathology, and Gregory A. Hoover, Department of Entomology, The Pennsylvania State University, University Park 16802; Elisa Angelini, Centro di Ricerca per la Viticoltura, Consiglio per la Ricerca e la Sperimentazione in Agricoltura, Conegliano, Italy; and Gary W. Moorman, Department of Plant Pathology, The Pennsylvania State University, University Park 16802

\begin{abstract}
Herath, P., Hoover, G. A., Angelini, E., and Moorman, G. W. 2010. Detection of elm yellows phytoplasma in elms and insects using real-time PCR. Plant Dis. 94:1355-1360.

A rapid and accurate method to detect the common strain of elm yellows (EY) phytoplasma in elm and insect samples was developed using a real-time polymerase chain reaction (PCR) procedure based on the TaqMan minor-groove-binder probe. Primers and probe were designed based on the EY phytoplasma-specific translocation protein $\sec Y$ gene DNA sequence. Success of the DNA extraction procedure was evaluated by amplifying the chloroplast trnL gene of $U l$ mus americana. The real-time PCR assay reacted positively with EY and EY phytoplasma strain ULW DNA, an isolate which occurs in Europe. It did not cross-react with Illinois EY or aster yellows phytoplasma DNA, both of which are known to occur in elm trees in the United States, nor did it amplify several other phytoplasmas belonging to the $16 \mathrm{SrV}$ and other phylogenetic groups. The real-time PCR protocol was used to identify 30 EY-positive elm trees on The Pennsylvania State University, University Park campus. Threshold cycle $\left(\mathrm{C}_{\mathrm{T}}\right)$ values obtained from the EY phytoplasma-infected elm trees ranged from 15 to 37. EY phytoplasma was detected in several leafhopper taxa. This real-time PCR method can be used for the diagnostic screening of elm trees and for the identification of possible insect vectors of EY phytoplasma.
\end{abstract}

American elm (Ulmus americana L.) trees are well known for their value as shade trees because of their graceful, arching, vase-like architecture and tolerance to stressful conditions. Although Dutch elm disease greatly reduced the elm population in eastern North America in the mid1900 s, the availability of resistant cultivars has resulted in their reintroduction into managed landscapes (30). Elm yellows (EY; formerly, elm phloem necrosis) is a serious disease of elm trees for which there is no known resistance, except possibly in the complex hybrid Homestead (27). This disease is associated with the EY phytoplasma ('Candidatus Phytoplasma ulmi'), which is classified as a member of the "Elm Yellows" group (16SrV group) (23). On the basis of phylogenetic analysis of $16 \mathrm{~S}$ rDNA sequences, EY group phytoplasmas form a discrete subclade within the phytoplasma clade (23). Phytoplasmas are obligate pathogens that lack cell walls and probably diverged from gram-positive bacteria. In host plants, they inhabit the phloem sieve elements and live intra- and extracellularly within insect tissues $(19,22)$. Phytoplasmas are associated with

Corresponding author: G. W. Moorman

E-mail: gmoorman@psu.edu

Accepted for publication 22 July 2010.

doi:10.1094/PDIS-12-09-0783

(C) 2010 The American Phytopathological Society diseases of more than 1,000 plant species, causing devastating losses in both low- and high-value crops $(2,22)$. The common strain of EY phytoplasma, the Illinois EY strain (16SrVI group), and aster yellows phytoplasma (16SrI group) are three phytoplasmas that occur in elm trees (21) in the United States.

EY was first described in detail by Swingle in 1938 (28) but was reported as early as 1882 in the Ohio River valley $(3,28)$. EY phytoplasma is transmitted from infected to healthy trees in the United States by the whitebanded elm leafhopper, Scaphoideus luteolus Van Duzee (14,26). In laboratory-based disease transmission studies, Philaenus spumarius (L.) and Allygus atomarius (Fabricius) were reported to transmit the phytoplasma (24). Symptoms of EY include yellowing, epinasty, premature defoliation, and death of the tree. Yellow discoloration of the innermost bark (phloem) with an odor of wintergreen oil or maple syrup is sometimes noted in some species of elm (26). The Pennsylvania State University, University Park campus (PSU-UP) is home to over $300 \mathrm{elm}$ trees, one of the largest concentrated and managed populations of mature elm trees in the United States. In the summer and fall of 2007, campus arborists observed symptoms consistent with those of EY. Samples were analyzed by Dr. Ing-Ming Lee (United States Department of Agriculture [USDA], Beltsville, MD), who confirmed that the elm trees were infected with the common strain of the EY phytoplasma.
EY phytoplasma detection in both plant (Ulmus spp.) and insect hosts can be carried out using the polymerase chain reaction (PCR) followed by restriction fragment length polymorphism (RFLP) analysis of 16S rRNA gene amplicons $(5,6,8,27)$ or by DNA sequencing the PCR product. A rapid and sensitive diagnostic protocol, requiring less sample handling, that can be used for high-throughput sampling needed.

Real-time PCR has been applied to diagnose numerous phytoplasmas. Christensen et al. (9) developed a real-time PCR procedure for the universal detection of phytoplasma, and Hren et al. (20) and Baric et al. (4) reported on TaqMan-based approaches to detecting phytoplasma associated with grapevine yellows and apple proliferation, respectively. Angelini et al. (1) also developed a TaqMan assay to detect phytoplasma associated with grapevine yellows. Galetto et al. (15) and Torres et al. (29) developed SYBR green-based real-time PCR assays to diagnose apple proliferation phytoplasma. These diagnostic procedures based on real-time PCR are highly sensitive and specific and allow for high throughput and rapid sample processing when compared with other methods.

The objectives of the present study were to develop a rapid and accurate diagnostic method to detect the common strain of EY phytoplasma associated with elm trees and insects in a large number of samples, and to identify the EY phytoplasma-positive elm trees and possible insect vectors on the PSU-UP campus. The real-time PCR procedure developed is based on the TaqMan minor-groove-binder (MGB) probe and allows the high-throughput needed for mass screening of samples for EY.

\section{MATERIALS AND METHODS}

Collection of elm twig samples and phloem harvest. Twigs were collected in April 2008 at the PSU-UP from all elm trees in the proximity of three elm trees that had exhibited typical EY symptoms in 2007. From a given tree, one twig $(25 \mathrm{~cm}$ long and 0.5 to $1 \mathrm{~cm}$ in diameter) from each cardinal direction was obtained. Phloem tissue collected from these four twigs was pooled and considered as a single sample. In total, 79 elm trees were sampled. A longitudinal slit was made in the bark of each twig using a clean razor blade, the twig was girdled at the top and 
the bottom of the slit, and the bark was removed. Inner cells of the bark (phloem) were scraped with the razor blade from each twig and placed in a 2-ml sterile centrifuge tube (Safe-Lock, Eppendorf) with two 5-mm-diameter glass beads and a small amount of sterile quartz sand. Midveins of the leaves were also sampled from a few trees. Special care was taken to prevent cross-contamination of samples by using a new razor blade, new nitrile gloves, and a clean paper towel on which the harvesting was done for each sample. Phloem harvesting was done in a room separate from where all other procedures were performed.

DNA extraction. Two methods were initially used to extract DNA from phloem tissue samples: (i) Qiagen DNeasy Plant Mini Kit protocol (Qiagen, CA) and (ii) the cetyltrimethylammonium bromide (CTAB)-Qiagen method used routinely in Dr. Ing-Ming Lee's lab (23). The Qiagen DNeasy Plant Mini Kit manufacturer's protocol was slightly modified as follows. Phloem tissue $(0.025 \mathrm{~g}$ fresh weight per sample) was macerated using a TissueLyser II (Qiagen, Retsch Inc., PA) at $30 \mathrm{~Hz}$ for $2 \mathrm{~min}$. Then, $500 \mu \mathrm{l}$ of Qiagen AP1 buffer was added and the mixture was centrifuged for $2 \mathrm{~min}$ at $16,000 \times \mathrm{g}$. About $400 \mu \mathrm{l}$ of the sample was removed and mixed with $4 \mu \mathrm{l}$ of RNase A. The rest of the procedure was as defined by the manufacturer's instructions. In the alternative DNA extraction procedure, CTAB buffer (2.5\% CTAB, $100 \mathrm{mM}$ Tris, $1.4 \mathrm{M} \mathrm{NaCl}$, $50 \mathrm{mM}$ EDTA, $1 \%$ polyvinylpyrrolidone, and $0.2 \%$ 2-mercaptoethanol) was used rather than Qiagen's AP1 buffer to homogenize the phloem tissue. The rest of the procedure was that of the Qiagen DNeasy Plant Mini Kit. A water blank was included in each set of DNA extractions in order to detect possible cross-sample contamination. Total nucleic acid concentration was quantified using a Nanodrop 1000 spectrophotometer (version 3.6; Thermo Fisher Scientific Inc., DE).

Design of primers and probe for realtime PCR. Primers and the TaqMan probe (Table 1) were designed based on the EY phytoplasma-specific protein translocation secY gene DNA sequence (GenBank accession no. AY 197690) using 'Primer Express' software (version 2.0; Applied Biosystems Inc., Foster City, CA). Primers and TaqMan MGB probe were manufactured by Integrated DNA Technologies
(IDT, Coralville, IA) and Applied Biosystems, respectively. The TaqMan MGB probe was an oligonucleotide containing fluorescent dye 6-carboxyfluorescein (FAM) as a reporter at the $5^{\prime}$ end, an MGB moiety, and a nonfluorescent quencher dye at the $3^{\prime}$ end. The success of the DNA extraction procedures was evaluated by amplifying the chloroplast trnL gene of $U$. americana (GenBank accession no. AF501593). Primers and TaqMan MGB probe (Table 1) for the endogenous controls were manufactured by Applied Biosystems

TaqMan real-time PCR. Real-time PCR assays were carried out in the Penn State Genomics Core Facility on an ABI PRISM 7300 (Applied Biosystems Inc.) in MicroAmp optical 96-well plates. Each reaction was performed in a total volume of $25 \mu \mathrm{l}$, containing $5 \mu \mathrm{l}$ of template DNA and $1 \times$ TaqMan Universal PCR Master Mix (Applied Biosystems Inc.). The final concentration of each primer was $400 \mathrm{nM}$. The probe was used at a final concentration of $200 \mathrm{nM}$. Two controls were used in each assay. Reverse-transcription (RT)PCR-grade water (Ambion Inc. division of Applied Biosystems Inc.) was used as a negative control to detect possible crosswell contamination. DNA from EY phytoplasma-infected periwinkle was used as a positive control. DNA of the EY phytoplasma (common strain) extracted from periwinkle (Catharanthus roseus L.) was kindly provided by Dr. Ing-Ming Lee (USDA). The thermal cycling parameters used were $2 \mathrm{~min}$ at $50^{\circ} \mathrm{C}$ for Uracil-Nglycosylase activation and $10 \mathrm{~min}$ at $95^{\circ} \mathrm{C}$ for AmpliTaq Gold activation, followed by 40 cycles of denaturation at $95^{\circ} \mathrm{C}$ for $15 \mathrm{~s}$ and $1 \mathrm{~min}$ of annealing or extension at $60^{\circ} \mathrm{C}$. The threshold cycles $\left(\mathrm{C}_{\mathrm{T}} \mathrm{s}\right)$ were determined by plotting normalized fluorescence $(\Delta R n)$ against cycle number. The results of the amplifications were analyzed using the Sequence Detection software (version 1.2.2; Applied Biosystems Inc.). The baseline was automatically set and the fluorescent threshold was set manually to intersect the exponential phase of the amplification curves. Each sample was run in triplicate in the same plate, and the sample was considered $\mathrm{EY}$ positive when all three replicates showed florescence signals at $C_{T}$ values of less than or equal to 38 . A threshold $\mathrm{C}_{\mathrm{T}}$ value of 38 was chosen because, in preliminary work, no EY-positive samples were found with triplicate $C_{T}$ values greater than 38 . Trees that repeatedly had fewer than three replicates with $\mathrm{C}_{\mathrm{T}}$ values of 38 or higher and exhibited no symptoms were considered EY negative. The efficiency $(e)$ and the correlation coefficient $\left(R^{2}\right)$ of the real-time PCR assay is assessed by establishing a standard curve using known template DNA concentrations (16). DNA samples obtained from EY phytoplasma-infected trees were extracted using the Qiagen protocol and used as templates. For each standard curve, the initial concentration of the DNA ranged between 46 and $57 \mathrm{ng} / \mu \mathrm{l}$. Standard curves were established based on five DNA concentrations prepared by 10 -fold serial dilutions. Each point of the standard curve was obtained from the mean value of two replicates. Efficiency of the real-time PCR assay was evaluated by plotting the $\mathrm{C}_{\mathrm{T}}$ values against the log of each known DNA concentration in the dilution series. The slope of the standard curve indicates the efficiency $e=\left[10^{(-1 / \text { slope })}\right]-1$ of the assay. A standard curve slope of -3.32 indicates a PCR reaction with $100 \%$ efficiency. When the PCR reaction has $100 \%$ efficiency, the template DNA doubles during each PCR cycle in the exponential phase (16). The $R^{2}$ value indicates how well the data fit the standard curve or the reproducibility of the replicates. Ideally, $R^{2}$ is 1 , but 0.999 is generally the maximum value (7).

Specificity of assay. The specificity of the primers and probe were first tested against the DNA of two phytoplasmas known to occur in elm trees in the United States (Table 2): Illinois EY phytoplasma strain (16SrVI group) and the aster yellows phytoplasma (16SrI group; DNA extracted from an infected Echinaceae sample submitted to the Pennsylvania State University, Department of Plant Pathology's Plant Disease Clinic). Subsequently, six phylogenetically diverse phytoplasmas belonging to different phylogenetic groups and which have never been isolated from elm were tested: Phi 250, clover phyllody; FBP, faba bean phyllody; AshY, ash yellows; VAC, Vaccinium witches' broom; $\mathrm{BA}$, stolbur; and AT, apple proliferation (Table 2). Finally, another six phytoplasmas belonging to the same phylogenetic group as the EY phytoplasma were tested: ULW, European EY; HD1, hemp dogbane yellows; ALY, Italian alder yellows; RS, rubus stunt; and FD-C and FD-D, Flavescence dorée type $\mathrm{C}$ and $\mathrm{D}$ from infected field-grown grapevines collected in North-

Table 1. Primers and probe sequences for detection of the common strain of elm yellows (EY) phytoplasma secY gene and the Ulmus americana trnL chloroplast gene

\begin{tabular}{lcclc}
\hline Name & Specificity & Amplicon & \multicolumn{1}{c}{ Sequence $\mathbf{5}^{\prime}-\mathbf{3}^{\prime}$} & Gene \\
\hline EY-1332-F & EY & $81 \mathrm{bp}$ & TTT AGC AGG AAG TGC AAT ATC TAA ACA & secY \\
EY-1332-R & EY & $\ldots$ & GAT TCT AAA GCA ACA CCG ACA ATA ATT & secY \\
EY-1332-probe & EY & $\ldots$ & 6FAM-CTT TTG GCG GGA CTA GT-MGB NFQ & secY \\
Elm-869-F & Ulmus & $85 \mathrm{bp}$ & CCC TTT TCA TCT TTT TAA TTG ACA TAG AC & trnL \\
Elm-869-R & Ulmus & $\ldots$ & GCT GAG CTA TCC CGA CCA TTT & trnL \\
Elm-869-probe & Ulmus & $\ldots$ & 6 FAM-CCA ATC CTC TAT TAA AAT GAG GAT GAT GCG TC-MGB NFQ & trnL \\
\hline
\end{tabular}


ern Italy (Table 2). Specificity of the primers (primer pairs EY 1332 and Elm 869) was also evaluated by using SYBR green and establishing a melting curve. Amplification conditions consisted of an incubation step at $95^{\circ} \mathrm{C}$ for $10 \mathrm{~min}$ followed by DNA amplification for 40 cycles at $95^{\circ} \mathrm{C}$ for $15 \mathrm{~s}$ and $60^{\circ} \mathrm{C}$ for $1 \mathrm{~min}$. A melting curve temperature profile was obtained by heating to $95^{\circ} \mathrm{C}$ for $15 \mathrm{~s}, 60^{\circ} \mathrm{C}$ for $30 \mathrm{~s}$, and $95^{\circ} \mathrm{C}$ in $15 \mathrm{~s}$.

Phytoplasma distribution in individual elm trees. To examine the distribution of EY phytoplasma in a given tree, samples were collected from two EY phytoplasma-infected trees (designated as trees 29-37 and C4 at PSU-UP), from the soil line to the top-most twigs, as the trees were felled in June 2008. Those trees had exhibited symptoms of EY in 2007. Tree 29-37 had a single trunk while $\mathrm{C} 4$ had two large trunks (designated as north and south) dividing about $1 \mathrm{~m}$ above the soil line. Twigs, trunk, and leaf samples were collected from each of the two trees. To sample foliage, leaf veins from several leaves were pooled and considered as one sample. DNA was extracted using the Qiagen DNeasy Plant Mini Kit protocol and the presence of EY phytoplasma was determined by using the TaqMan real-time PCR protocol described above.

Mass sampling of elm trees and insects. As part of a campus-wide plant management system, each elm tree on campus had previously been assigned a permanent alphanumeric designation and its latitude and longitude determined. The sampling of the elm trees at PSU-UP began in May 2008 and continued through September 2008. Some trees were sampled repeatedly while others were added as the survey area gradually increased to include trees neighboring campus. During May to July 2008, 286 samples were taken. Some of the trees that had tested positive for EY had been removed. In August and September 2008, all the trees that had not been removed following the July sampling were sampled again along with additional trees, giving a total of 342 trees sampled in August and September 2008. The campus arborists used pruning shears to remove twigs (approximately $25 \mathrm{~cm}$ long and 0.5 to $1 \mathrm{~cm}$ in diameter) which were then placed in plastic bags, labeled, and transported to the lab for storage at $2{ }^{\circ} \mathrm{C}$ until processed. In May to July 2008, one twig was obtained from each tree. In August and September 2008, four twigs (one twig from each cardinal direction) were obtained from each tree. The four twigs per tree constituted a single sample to account for the possible uneven distribution of phytoplasma within a tree. Phloem from the twigs was harvested as described previously. DNA was extracted using the Qiagen DNeasy Plant Mini Kit protocol, and the presence of EY phytoplasma was determined by using the TaqMan real-time PCR protocol.

In order to collect leafhoppers, a large yellow sticky card $(0.25$ by $0.4 \mathrm{~m})$ was suspended in the upper canopy of an elm at six different sites at or near the PSU-UP. Every 2 weeks from May to July 2008, leafhoppers captured on the cards were removed and sorted by morphological group. Depending upon the size of the insect and number of insects, 1 to 30 individuals from a morphological group were placed in 2-ml sterile centrifuge tubes (Safe-Lock, Eppendorf) with two 5-mmdiameter glass beads and a small amount of sterile quartz sand. Samples were macerated using a TissueLyser II (Qiagen) at $30 \mathrm{~Hz}$ for $2 \mathrm{~min}$. Approximately 500 to $1,000 \mu \mathrm{l}$ of Qiagen AP1 buffer (depending on the size and number of individuals in the tube) was added and the mixture cen- trifuged for $2 \mathrm{~min}$ at $16,000 \times g$. About $400 \mu \mathrm{l}$ of the sample was removed and mixed with $4 \mu$ l of RNase A. The remainder of the procedure followed the Qiagen DNeasy Plant Mini Kit protocol (Qiagen). Leafhoppers carrying EY phytoplasma were identified using the TaqMan real-time PCR assay. The success of the DNA extraction procedures was evaluated by amplifying the 18S rRNA gene of the leafhoppers by using Eukaryotic 18S rRNA TaqMan endogenous control (Applied Biosystems Inc.).

\section{RESULTS}

Performance of the protocol. DNA extractions were performed on a few phloem samples using the Qiagen DNeasy Plant Mini Kit protocol and the CTAB-Qiagen method used routinely in other laboratories. Both the Qiagen and CTAB-Qiagen DNA methods effectively extracted EY phytoplasma DNA. Subsequent tests for the presence or absence of phytoplasma DNA yielded similar results (data not shown) regardless of the extraction method used. Primers and the probe used for the detection of EY phytoplasma were based on the DNA sequence of the $\sec Y$ gene starting at position 1,332 and ending at position 1,413 and produced an 81-bp amplicon. As explained in Materials and Methods, a $\mathrm{C}_{\mathrm{T}}$ value of 38 was used as the threshold to designate a sample as being positive for EY phytoplasma DNA. The $\mathrm{C}_{\mathrm{T}}$ values for EY phytoplasma detection varied from 15 to 35 . In the case of the chloroplast $\operatorname{trnL}$ of $U$. americana, used to evaluate the success of the DNA extraction protocol, the $\mathrm{C}_{\mathrm{T}}$ values varied from 12 to 25 .

TaqMan real-time PCR assays using standard samples with known DNA concentrations resulted in standard curves with an $R^{2}$ greater than 0.994 . Slopes of the regression lines showed values ranging

Table 2. Phytoplasmas used in this work in the verification of the specificity of the real-time polymerase chain reaction test developed to detect DNA of the common strain of elm yellows in Ulmus and insect tissues

\begin{tabular}{lll}
\hline 16S rRNA phytoplasma group and subgroup & Strain abbreviation, name & Provided by \\
\hline 16Sr I (Aster yellows group) & Aster yellows & G. W. Moorman \\
I-A & Phi 250, Clover phyllody & E. Boudon-Padieu \\
I-C & FBP, Faba bean phyllody & E. Boudon-Padieu \\
16Sr II (Peanut witches'- broom group) & & L. Carraro \\
II-C & VAC, Vaccinium witches' broom & E. Boudon-Padieu \\
16Sr III (X-disease group) & ULW, European elm yellows & E. Boudon-Padieu \\
III-F & ALY, Italian alder yellows & E. Boudon-Padieu \\
16Sr V (Elm yellows group) & HD1, Hemp dogbane yellows & E. Angelini \\
V-A & FD-C, Flavescence dorée & E. Angelini \\
V-C & FD-D, Flavescence dorée & C. Marcone \\
V-D & RS, Rubus stunt & I. M. Lee \\
V-E & Illinois elm yellows & E. Boudon-Padieu \\
VI-C & AshY, Ash yellows & A. Bertaccini \\
16Sr VII (Ash yellows group) & & L. Carraro \\
VII-A $16 \mathrm{Sr} \mathrm{X} \mathrm{(Apple} \mathrm{proliferation} \mathrm{group)}$ & AT, Apple proliferation & \\
X-A & BA, Stolbur & \\
16Sr XII (Stolbur group) & & \\
XII-A & & \\
\hline
\end{tabular}


between -3.480 and -3.105 , indicating that the PCR efficiency ranged from 93.78 to $109.92 \%$ (Figs. 1 and 2). A BLAST search for the EY phytoplasma secY gene amplicon did not reveal similarity with other phytoplasma sec $Y$ genes, except for 93 to $95 \%$ identity with FD, HD1, RS, and SpaWB (Spartium witches' broom) phytoplasma nucleotide sequences. To determine the specificity of the EY 1332 primers and probe used to detect the common strain of EY phytoplasma, these were tested against other phytoplasmas known to occur in elm in the United States (the Illinois EY and aster yellows phytoplasmas), and no fluorescence signal was detected, indicating that the EY 1332 primers and probe did not cross react with Illinois EY or aster yellows DNA. Similar results were obtained when testing the TaqMan system against six other phytoplasmas belonging to the $16 \mathrm{SrV}$ (including FD, HD1, and RS) and six phytoplasmas belonging the other ribosomal groups (Table 2). The EY 1332 primers and probe reacted positively only with the ULW phytoplasma, which is known to infect elm in Europe and is closely related to the EY phytoplasma. A faint cross reaction also was observed with HD1 phytoplasma; however, the $\mathrm{C}_{\mathrm{T}}$ values were higher than 38 . Thus, the sample would be considered negative to the EY phytoplasma according to our interpretation of the results of the real-time PCR. Specificity of the assay was also confirmed by obtaining a unique melting point peak at $71.5^{\circ} \mathrm{C}$ with $\mathrm{EY} 1332$ primers and SYBR green. Elm 869 primers with SYBR green also produced a unique melting point peak at $74.5^{\circ} \mathrm{C}$.

EY phytoplasma distribution in individual elm trees. TaqMan real-time PCR detected EY phytoplasma DNA in all woody samples from two EY-positive trees (tree nos. 29-37 and C4) that were thoroughly sampled during felling (Tables 3 and 4). $C_{T}$ values did not reveal a gradient in $E Y$ phytoplasma concentration from the base of the trees to the tops. Phytoplasma was detected in three of the four foliage samples.

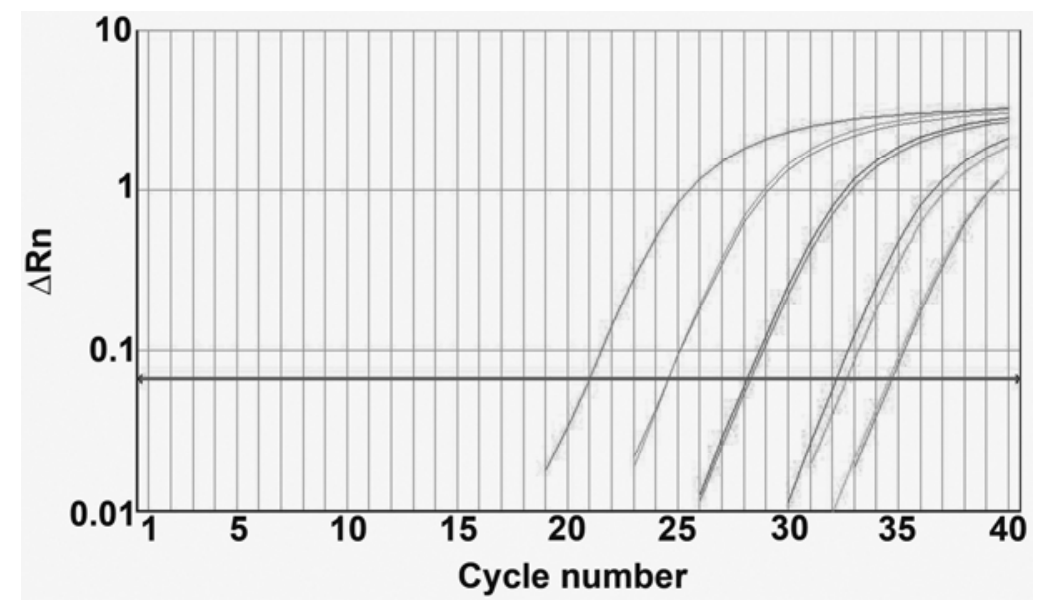

Fig. 1. Plot of real-time polymerase chain reaction amplification of a dilution series $\left(10^{0}\right.$ to $\left.10^{-4}\right)$ of extract taken from elm tissue containing the common strain of phytoplasma associated with elm yellows. $\Delta \mathrm{Rn}$ : normalized fluorescence.

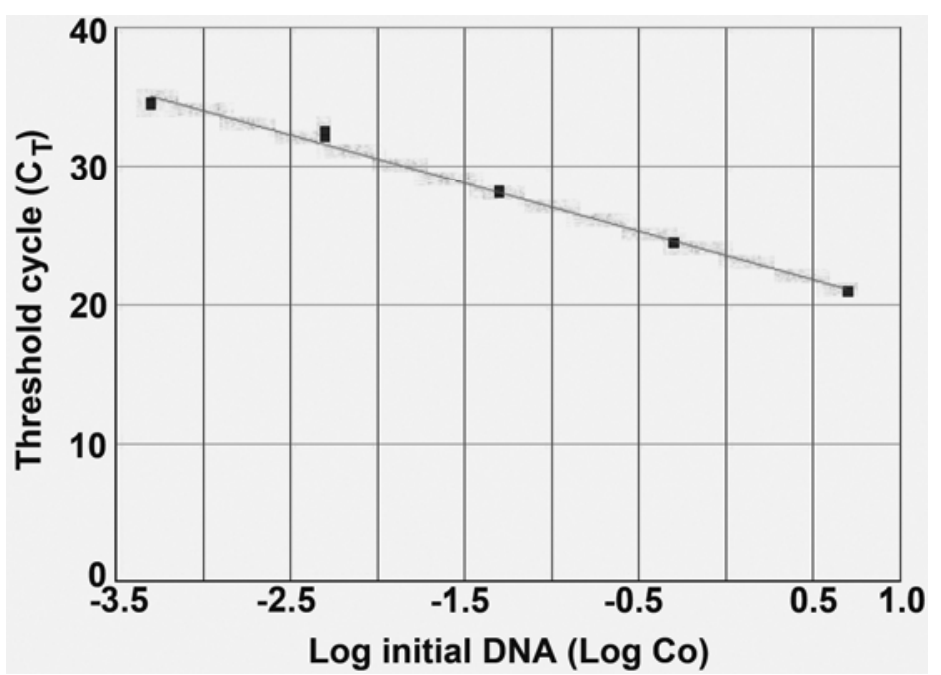

Fig. 2. Standard curve obtained with elm yellows (EY) 1332 primers and probe at five concentrations $\left(10^{0}\right.$ to $\left.10^{-4}\right)$ of extract taken from elm tissue containing the common strain of phytoplasma associated with EY. Slope $=-3.4803 ; R^{2}=0.9899$.
Screening of elm trees and insects for EY phytoplasma. In May to July 2008, 286 elm trees were tested using DNA extracted from twigs and real-time PCR, and 19 trees were positive for EY phytoplasma. Foliage samples from some of the 19 trees indicated that they were infected with the EY phytoplasma. Some of the infected trees were removed before the next sampling. In the August and September 2008 sampling of 342 trees (including some that had previously been sampled), EY phytoplasma was detected in 20 trees: 11 new detections and 9 that had been previously detected. Some real-time PCR-positive trees showed typical EY symptoms of phloem discoloration, yellowing of the leaves, wintergreen odor, and dying branches whereas others exhibited no symptoms. $\mathrm{C}_{\mathrm{T}}$ values obtained from the EY phytoplasma-infected elm trees ranged from 15 to 37. The majority of the EY phytoplasma-infected trees from the May to July 2008 sampling had $\mathrm{C}_{\mathrm{T}}$ values ranging between 31 and 35. Most of the EY trees from the August and September 2008 sampling had $\mathrm{C}_{\mathrm{T}}$ values between 26 and 30. EY-positive trees were located in two major clusters in the sampling area, one in the north-central (N40 $48.3^{\prime}$; W77 $\left.{ }^{\circ} 52.2^{\prime}\right)$ and the second in the southwest $\left(\mathrm{N} 40^{\circ}\right.$ 47.6'; ${\mathrm{W} 77^{\circ}}^{\circ} 51.9^{\prime}$ ) corner of PSU-UP, approximately $1,100 \mathrm{~m}$ apart.

Over 1,275 leafhoppers were captured on yellow sticky cards placed in apparently healthy elm trees from May to July 2008. Based on morphology (11-13,18), 17 different taxa in the family Cicadellidae were identified from the yellow sticky cards. Using the TaqMan real-time PCR method, EY phytoplasma was detected in the cicadellid genera Allygus, Colladonus, Empoasca, Erythronneura, Graphocephala, Homalodisca, Orientus, Scaphoideus, and Typhlocyba. The taxonomy of the species in these genera is being further analyzed. No attempt was made to determine what percentage of insects harbored the phytoplasma. $\mathrm{C}_{\mathrm{T}}$ values for EY phytoplasma in the insect extracts varied from 25 to 37 . Success of the DNA extraction procedure was evaluated by amplifying the $18 \mathrm{~S}$ rRNA gene of the leafhoppers. $C_{T}$ values ranged from 21 to 37 .

\section{DISCUSSION}

At present, identification of EY phytoplasma is based on nested PCR-RFLP analysis or sequencing of amplicons. These methods severely limit the number of samples that can be processed in a given length of time. Most commonly, EY phytoplasma detection by nested PCR-RFLP targets the $16 \mathrm{~S}$ rRNA gene $(5,6,8,27)$. Because of the highly conserved nature of this gene, it is not possible to design primers with high specificity for the $16 \mathrm{~S}$ rRNA gene of EY phytoplasma. The real-time PCR procedure developed in the present study provides a solution. Although great 
care must be taken during sample preparation to avoid cross-sample contamination regardless of the protocol used, no postamplification sample handling is required with real-time PCR. The real-time PCR technique based on TaqMan (MGB probe) chemistry amplifies the common strain of EY phytoplasma but not Illinois EY or aster yellow phytoplasma DNA, two other phytoplasmas known to occur in elm trees in the United States. It reacts positively with ULW phytoplasma, an isolate which occurs in elm trees in Europe, whereas it does not amplify several other phytoplasmas belonging to the $16 \mathrm{SrV}$ and other phylogenetic groups. Specificity of the primers was confirmed by obtaining a unique melting curve when real-time PCR reactions were performed using SYBR green. This is the first report of a real-time PCR technique developed to detect the common strains of American and European EY phytoplasmas. The efficiency of the present method ranged from 93.78 to $109.92 \%$ while $R^{2}$ was 0.994 , thereby illustrating that the real-time PCR assay developed here is highly reliable. The primers and probes were designed to have a small number of base pairs in order to increase the sensitivity and the efficiency of the assay.

Woody plants usually contain high levels of phenolic compounds and polysaccharides that can inhibit enzymes used in PCR (25). To solve this problem, DNA extractions from woody plants are usually performed using the CTAB method (17), requiring a fume hood to remove the toxic fumes of 2-mercaptoethanol. In order to establish a quick, simple DNA extraction protocol, the CTAB procedure followed by Qiagen was compared with bypassing the CTAB step and using only the Qiagen procedure. Regardless of the DNA extraction protocol, similar results were obtained when isolates were tested with real-time PCR (data not shown). Thus, the Qiagen DNA protocol can be used, thereby eliminating risks associated with the handling of 2-mercaptoethanol.

High-quality DNA is essential for successful PCR analyses. Therefore, an endogenous control, the elm chloroplast trnL gene sequence, was used to evaluate the quality of the extracted DNA and to distinguish between healthy plant material and false-negative samples. A similar approach was used to diagnose grapevine yellows phytoplasma in grape (1) and for the simultaneous amplification of apple proliferation phytoplasma and the Malus domestica chloroplast $t r n L$ gene (4). The quality and quantity of the isolated DNA can be evaluated using the $\mathrm{C}_{\mathrm{T}}$ values of the endogenous control. Detection of chloroplast $\operatorname{trn} L$ gene DNA at higher $\mathrm{C}_{\mathrm{T}}$ values indicates a low amount of elm DNA and may reflect lower amounts of phytoplasma DNA in the reaction. In the present research, in order to confirm result reliabil- ity, samples with high $\mathrm{C}_{\mathrm{T}}$ values in the trnL reactions were extracted again and retested in the real-time PCR assay. Potential effects of plant host material inhibition was tested by mixing phytoplasma DNA with extracts from healthy elm plant material that had already been tested with realtime PCR and confirmed to be free of EY phytoplasma DNA. There were no detectable inhibitory effects when extracts from healthy elm were added (data not shown).

The presence of phytoplasma in all woody samples of the two EY phytoplasma-infected trees indicates that phytoplasma may be distributed throughout the woody portions of the tree. Based on nested PCR-RFLP analysis, BoudonPadieu et al. (6) reported similar observations of European EY phytoplasma in stems, younger branches, roots, and rootlets of infected trees. Phytoplasmas overwinter in the roots and in the spring move upward, spreading irregularly in the shoots (10), and distribution becomes more uniform over time (31). Christensen et al. (9) developed quantitative PCR and bioimaging methods to quantify and localize a wide range of phytoplasma strains in $C$. roseus and Euphorbia pulcherrima. According to those studies, accumulation of phytoplasmas in source leaves of E. pulcherrima was higher than in the petioles of source leaves or in the stems. They also reported very low levels of phytoplasma accumulation in sink organs (root and sink leaves).

We report here a method to screen a large number of samples of elm trees for the EY phytoplasma over a relatively short period of time using the Qiagen extraction and TaqMan real-time PCR protocol. The highest number of infected trees was observed in August and September 2008. This may have been due to an increase in phytoplasma titers over time, the increased number of trees sampled, or the increased number of twigs collected per tree. In May to July 2008 , only one twig per tree was sampled and, hence, some EY phytoplasma-infected individuals may have been missed because of uneven distribution of EY phytoplasma in a recently infected tree (10). Increasing the number of twigs sampled from a given tree may ameliorate this

Table 3. Distribution of the common strain of the elm yellows phytoplasma in elm 29-37a

\begin{tabular}{lc}
\hline Sample location (subsample no.) & $\mathbf{C}_{\mathbf{T}} \mathbf{v a l u e}^{\mathbf{b}}$ \\
\hline Stump bark (29-37.2.1) & 25 \\
Sprouts at soil line (29-37.2.2) & 26 \\
Bark 1.2 m from soil line (29-37.2.3) & 22 \\
Small branch on main trunk, 15 m from soil line (29-37.2.4) & 24 \\
Main trunk bark 18 m from soil line (29-37.2.5) & 23 \\
Bark from small branch at top of main trunk 22.5 m from soil line (29-37.2.6) & 21 \\
Leaves that were with the subsample 29-37.2.6 (29-37.2.6L) & 29 \\
Trunk bark at 22.5 m from soil line (29-37.2.7) & 26 \\
Bark from major middle branch 9 m from soil line (29-37.2.8) & 24 \\
Small branches from major middle 9 m from soil line (29-37.2.9) & 31 \\
Leaves that were with the subsample 29-37.2.9 (29-37.2.9L) & 0 \\
\hline
\end{tabular}

a Twig, trunk, and leaf samples were analyzed using the TaqMan real-time polymerase chain reaction (PCR).

${ }^{\mathrm{b}}$ Forty real-time PCR cycles were performed at Penn State. Samples were considered positive if the threshold cycle $\left(\mathrm{C}_{\mathrm{T}}\right)$ value was $\leq 38$ in triplicate samples.

Table 4. Distribution of the common strain of the elm yellows phytoplasma in elm C4a

\begin{tabular}{lc}
\hline Sample location (subsample no.) & $\mathbf{C}_{\mathbf{T}}$ value $^{\mathbf{b}}$ \\
\hline Bark of north trunk near soil line (C4.2.1) & 20 \\
Sprouts north trunk 4.5 m from soil line (C4.2.2) & 37 \\
Bark of north trunk 6 m from crotch (C4.2.3) & 31 \\
Bark of major branch off main north trunk 9 m from soil line (C4.2.4) & 36 \\
Bark of north trunk 9 m from soil line (C4.2.5) & 17 \\
Twigs on north trunk 12 m from soil line (C4.2.6) & 24 \\
Leaves from subsample C 4.2.6 12 m from soil line (C4.2.6L) & 35 \\
Twigs on north trunk 19.5 m from soil line (C4.2.7) & 24 \\
Bark of north trunk 19.5 m from soil line (C4.2.8) & 18 \\
Twigs on north trunk 21 m from soil line (C4.2.9) & 32 \\
Twigs on north trunk at 22.5 m from soil line (C4.2.10) & 28 \\
Top-most twigs (C4.2.11) & 32 \\
Leaves that were with the subsample C4.2.11 (C4.2.11L) & 35 \\
Top-most twigs from south trunk (C4.2.12) & 32 \\
Bark of south trunk 6 m from soil line (C4.2.13) & 19 \\
Bark from branch off south trunk 4.5 m from soil line (C4.2.14) & 19 \\
Bark from branch off south trunk 7.5 m from soil line (C4.2.15) & 19 \\
Bark from branch off south trunk 15 m from soil line (C4.2.16) & 30 \\
Twigs at top of branch off south trunk (C4.2.17) & 33 \\
\hline
\end{tabular}

a Twig, trunk, and leaf samples were analyzed using the TaqMan real-time polymerase chain reaction (PCR).

${ }^{\mathrm{b}}$ Forty real-time PCR cycles were performed at Penn State. Samples were considered positive if the threshold cycle $\left(\mathrm{C}_{\mathrm{T}}\right)$ value was $\leq 38$ in triplicate samples. 
problem. The large number of infected trees in the north-central part of campus may have been a result of high leafhopper vector activity there as a consequence of a decision to not spray those trees with insecticide. Although the spraying targets the elm bark beetles responsible for vectoring Dutch elm disease, these insecticide applications may also suppress leafhoppers. Insecticide applications had not been performed for several years in that area at the request of residents in the adjacent neighborhood. The incubation period of EY is about 3 months in small elm trees and 9 to 10 months or more in larger ones (26). Based on this, trees that did not exhibit any symptoms but were positive for EY phytoplasma may have been infected in previous years. The presence of EY phytoplasma DNA in an insect collected from an elm tree simply indicates that the insect fed on an EY phytoplasma-infected elm and ingested the phytoplasma but is not proof that it is able to vector the pathogen. More research is required to prove that the insects found to contain EY phytoplasma DNA in this study can actually vector the phytoplasma to elm trees.

In conclusion, the Qiagen DNeasy Plant Mini Kit protocol combined with the TaqMan real-time PCR technique provides an alternative to the CTAB extraction and is a high-throughput method for EY phytoplasma detection in elm trees and insects that is rapid, specific, reproducible, and reliable.

\section{ACKNOWLEDGMENTS}

We thank I. M. Lee for the EY DNA he provided; L. Filippin for performing the tests on the European strains; R. Leonard, C. Riley, and E. Dice for their technical assistance throughout this study; Penn State arborists J. Dice, K. Edson, D. Beben, C. Fetterolf, G. Peoples, and C. Smith for their expertise in collecting elm samples; D. Grove and A. Price of the Penn State Genomics Core Facility for their invaluable assistance; and S. M. Witiak and I. Seidl-Adams for useful discussions during this work. This research was funded by The Pennsylvania State University.

\section{LITERATURE CITED}

1. Angelini, E., Bianchi, G. L., Filippin, L., Morassutti, C., and Borgo, M. 2007. A new TaqMan method for the identification of phytoplasmas associated with grapevine yellows by real-time PCR assay. J. Microbiol. Methods 68:613-622.

2. Bai, X., Correa, V. R., Toruno, T. Y., Ammar,
E. D., Kamoun, S., and Hogenhout, S. A. 2009. AY-WB Phytoplasma secretes a protein that targets plant cell nuclei. Mol. PlantMicrobe Interact. 22:18-30.

3. Baker, W. L. 1948. Transmission by leafhoppers of the virus causing phloem necrosis of American elm. Science 108:307-308.

4. Baric, S., and Dalla-Via, J. 2004. A new approach to apple proliferation detection: a highly sensitive real-time PCR assay. J. Microbiol. Methods 57:135-145.

5. Bertelli, E., Tegli, S., Sfalanga, A., and Surico, G. 2002. Detection of phytoplasmal DNA in flowers and seeds from elm trees infected with elm yellows. Phytopathol. Mediterr. 41:259265.

6. Boudon-Padieu, E., Larrue, J., Clair, D., Hourdel, J., Jeanneau, A., Sforza, R., and Collin, E. 2004. Detection and prophylaxis of elm yellows phytoplasma in France. Invest. Agrar. Sist. Recur. For. 13:71-80.

7. Bustin, S. 2004. AZ of Quantitative PCR. International University Line, La Jolla, CA.

8. Carraro, L., Ferrini, F., Ermacora, P., Loi, N., Martini, M., and Osler, R. 2004. Macropsis mendax as a vector of elm yellows phytoplasma of Ulmus species. Plant Pathol. 53:9095.

9. Christensen, N. M., Nicolaisen, M., Hansen, M., and Schulz, A. 2004. Distribution of phytoplasmas in infected plants as revealed by real-time PCR and bioimaging. Mol. PlantMicrobe Interact. 17:1175-1184.

10. Chuche, J., and Thiéry, D. 2009. Cold winter temperatures condition the egg-hatching dynamics of a grape disease vector. Naturwissenschaften 96:827-834

11. Delong, D. 1948. The leafhoppers, or Cicadellidae, of Illinois (Eurymelinae-Balcluthinae). Ill. Nat. Hist. Surv. Bull. 24:91-376.

12. Delong, D. M. 1939. A review of the genus Scaphoideus. Proc. Entomol. Soc. Wash. 41:33-45.

13. Dietrich, C. 2005. Keys to the families of Cicadomorpha and subfamilies and tribes of Cicadellidae (Hemiptera: Auchenorrhyncha). Fla. Entomol. 88:502-517.

14. Drooz, A. 1985. Insects of eastern forests. U. S. Dep. Agric. For. Serv. Misc. Publ. 1426:608.

15. Galetto, L., Bosco, D., and Marzachi, C. 2005. Universal and group-specific real-time PCR diagnosis of flavescence doree $(16 \mathrm{Sr}-\mathrm{V})$, bois noir (16Sr-XII) and apple proliferation (16Sr$\mathrm{X})$ phytoplasmas from field-collected plant hosts and insect vectors. Ann. Appl. Biol. 147:191-201.

16. Ginzinger, D. 2002. Gene quantification using real-time quantitative PCR an emerging technology hits the mainstream. Exp. Hematol. 30:503-512.

17. Green, M., Thompson, D., and MacKenzie, D. 1999. Easy and efficient DNA extraction from woody plants for the detection of phytoplasmas by polymerase chain reaction. Plant Dis. 83:482-485.

18. Hamilton, K. G. A. 1985. Leafhoppers of ornamental and fruit trees in Canada. Agric. Can. Publ. 1779/E:1-71.

19. Hogenhout, S. A., Oshima, K., Ammar, E. L. D., Kakizawa, S., Kingdom, H. N., and Namba, S. 2008. Phytoplasmas: bacteria that manipulate plants and insects. Mol. Plant Pathol. 9:403-423.

20. Hren, M., Boben, J., Rotter, A., Kralj, P., Gruden, K., and Ravnikar, M. 2007. Real-time PCR detection systems for Flavescence doree and Bois noir phytoplasmas in grapevine: comparison with conventional PCR detection and application in diagnostics. Plant Pathol. 56:785-796.

21. Jacobs, K., Lee, I., Griffiths, H., Miller, F., Jr., and Bottner, K. 2003. A new member of the clover proliferation phytoplasma group (16SrVI) associated with elm yellows in Illinois. Plant Dis. 87:241-246.

22. Lee, I. M., Davis, R. E., and GundersenRindal, D. E. 2000. Phytoplasma: phytopathogenic mollicutes. Annu. Rev. Microbiol 54:221-255.

23. Lee, I. M., Martini, M., Marcone, C., and Zhu, S. F. 2004. Classification of phytoplasma strains in the elm yellows group (16SrV) and proposal of Candidatus Phytoplasma ulmi for the phytoplasma associated with elm yellows. International J. Syst. Evol. Microbiol. 54:337347.

24. Matteoni, J., and Sinclair, W. 1988. Elm yellows and ash yellows. Pages 19-31 in: Tree Mycoplasma Diseases and Epidemiology. C. Hiruki, ed. University of Alberta Press, Edmonton, AB, Canada.

25. Osman, F., and Rowhani, A. 2006. Application of a spotting sample preparation technique for the detection of pathogens in woody plants by RT-PCR and real-time PCR (TaqMan). J. Virol. Methods 133:130-136.

26. Sinclair, W., and Lyon, H. 2005. Diseases of Trees and Shrubs. Comstock Publishing Associates, New York.

27. Sinclair, W. A., Townsend, A. M., Griffiths, H. M., and Whitlow, T. H. 2000. Responses of six Eurasian Ulmus cultivars to a North American elm yellows phytoplasma. Plant Dis. 84:12661270 .

28. Swingle, R. 1938. A phloem necrosis of elm. Phytopathology 28:757-759.

29. Torres, E., Bertolini, E., Cambra, M., Montón, C., and Martín, M. P. 2005. Real-time PCR for simultaneous and quantitative detection of quarantine phytoplasmas from apple proliferation (16SrX) group. Mol. Cell. Probes 19:334340 .

30. Townsend, A. M., Bentz, S. E., and Douglass, L. W. 2005. Evaluation of 19 American elm clones for tolerance to Dutch elm disease. $\mathrm{J}$. Environ. Hortic. 23:21-24

31. Wei, W., Kakizawa, S., Suzuki, S., Jung, H., Nishigawa, H., Miyata, S., Oshima, K., Ugaki, M., Hibi, T., and Namba, S. 2004. In planta dynamic analysis of onion yellows phytoplasma using localized inoculation by insect transmission. Phytopathology 94:244-250. 